\title{
Reproductive Performances of Bligon Goats in Different Agroecological Zones in Bantul Regency, Yogyakarta
}

\author{
Lusia Komala Widiastuti ${ }^{1}$, Sigit Bintara ${ }^{2}$, Nono Ngadiyono $^{3}$, Panjono Panjono ${ }^{3}$, \\ Bayu Andri Atmoko ${ }^{3}$ and I Gede Suparta Budisatria ${ }^{3 *}$
}

\author{
${ }^{1}$ Student of Animal Science, Faculty of Animal Science, Universitas Gadjah Mada \\ ${ }^{2}$ Department of Animal Genetics and Reproduction, Faculty of Animal Science, Universitas Gadjah Mada \\ ${ }^{3}$ Department of Animal Production, Faculty of Animal Science, Universitas Gadjah Mada \\ ${ }^{*}$ Corresponding author. Email: budisatria@ugm.ac.id
}

\begin{abstract}
Bligon goats in Bantul Regency are found in various agro-ecological zones, consisting of lowland and hilly areas, affecting reproductive performances. This study aimed to investigate the reproductive performances of the Bligon goats in different agro-ecological zones in the Bantul Regency. A total of 80 Bligon kept by farmers in the lowland and hilly area was observed and recorded. The data were analyzed descriptively and statistically using the Independent Sample T-Test. The results showed that Bligon kept by farmers in the lowland significantly have better reproductive performances $(\mathrm{P}<0.05)$ than hilly area, in terms of first mating age $(9.60 \pm 3.22 \mathrm{vs} .11 .07 \pm 2.41$ months $)$, first kidding age $(15.00 \pm 3.23$ vs. $16.70 \pm 2.53$ months $)$, post-partum mating $(4.75 \pm 2.23$ vs. $4.9 \pm 2.34$ months $)$, and litter size (1.62 \pm 0.58 vs. $1.37 \pm 0.49)$. In contrast, the length of pregnancy and the kidding interval were not significantly different between the kept by farmers in the lowland and hilly areas. It was $5.07 \pm 0.26$ vs. $5.10 \pm 0.30$ and $9.32 \pm 3.53$ vs. 9.37 \pm 3.83 months, respectively. It can be concluded that the Bligon goats kept by farmers in the lowland have better reproductive performance than hilly areas.
\end{abstract}

Keywords: Agro-ecological zones, Bligon goat, Reproductive performances.

\section{INTRODUCTION}

Goat is one type of small ruminant developed and found in various regions, provides an important role for rural communities, and contributes to increasing farmers' income [1,2]. It supports the distribution of goats throughout Indonesia, especially in rural areas of Java Island, and has become a leading livestock commodity in various regions, one of which is in Bantul Regency, Special Region of Yogyakarta.

One goat breed mostly kept by farmers is the Bligon goat, resulting in a crossbreeding program between male Kacang and female Etawah Grade goats. The rapid development of Bligon goats happened because many people have been interested in keeping Bligon goats, so the goats spread widely into different agro-ecological zones, consisting of lowland to hilly areas. These conditions could affect the reproductive performance of Bligon goats which are influenced by environmental factors (70\%) and genetic factors (30\%). These environmental factors like different geographical and climatic conditions in each agro-ecological zone. Differences in agro-ecological zones will have an impact on feed availability. In the lowland, intensive farming systems will produce a source of feed like residues and agricultural waste, while in hilly to high areas dominated by fields and forests, the availability of feed source, especially for goats, is usually dominated by leaves $[3,4]$.

Goats kept by farmers in high areas tend to have better reproductive performance than lowland, especially postpartum mating (PPM), kidding interval, and litter size. It is because crude protein content in the feed derived from leaves and legumes is higher [5]. A previous study stated that feeding goats with high-quality feed could improve productivity [6]. As long as sufficient feed and crop residues are available, keeping small ruminants can produce more kid/lamb, which benefits the farmers and contributes to higher economic results [7]. Therefore, this 
research aims to investigate the reproductive performance of Bligon goats in different agro-ecological zones consisting of lowland and hills areas in Bantul Regency, Special Region of Yogyakarta.

\section{MATERIAL AND METHODS}

\subsection{Materials}

The study was involved 45 farmers who kept goats, 21 farmers in the lowland, and 24 farmers in the hilly area. Farmers were selected by purposive sampling method with the criteria were having more than one year of experience on keeping Bligon goats. Goats used were 80 head of Bligon does, 40 does in the lowland, and 40 does in the hilly area. They had to have given birth at least once and have healthy and normal reproductive tracts to be considered.

\subsection{Methods}

Survey methods and direct observation on the fields were conducted to collect all of the study variables. The data obtained were then analyzed descriptively and quantitatively by statistical analysis using the Independent Sample t-test to compare the differences of does reproductive performances in the lowland and hilly. The analysis was powered by Statistical Product and Service Solutions (SPSS) 16.0 for the windows program.

\section{RESULT AND DISCUSSION}

\subsection{Age of First Mating}

There was a significant difference $(\mathrm{P}<0.05)$ in the age of first mating of Bligon goats in the lowland and hilly area. The average age of first mating for Bligon goats in the lowland was younger than in the hilly area. It could be due to farmers' lack of understanding of reproductive management in Bligon goats, resulting in goats being mated at a younger age in the lowland compared to farmers in the hilly area, and farmers' lack of appropriate information regarding the first mating age of does, resulting in farmers mating does as soon as the female goat shows estrus signs.

The average age of first mating of Bligon goats in the lowland was 9.6 months, and in the hilly area was 11.07 months (Table 1). Based on previous research, the average first mating age of Bligon goats was 14.9 months in the lowland and 13.8 months in the hilly area [5]. The average age of first mating in this study was slightly better. However, our study was still in line with the reproduction management found by another study, namely between 8 to 12 months [8].

\subsection{Length of Pregnancy}

The length of pregnancy is the time of fertilization to normal birth. The average length of pregnancy in the different agro-ecological zones did not significantly differ, namely 5.07 months in the lowland and 5.1 months in the hilly area. The length of pregnancy of Bligon goats ranges from 5 to 6 months $[5,9,10]$ and will birth three times in two years [11]. The length of pregnancy varies depending on the species, even between individuals within the same breed and genetic and environmental factors (internal and external).

\subsection{Age of First Kidding}

The average first kidding age for Bligon goats was 15 months in the lowland and 16.7 months in the hilly area (Table 1). The age of first kidding had a significant difference $(\mathrm{P}<0.05)$, with the average in the lowland being earlier than the previous research, namely 16.6 months in the first group and 17.3 months in the second group [12]. The age differences of first kidding are also influenced by the age of first mating (Table 1) and service per conception (S/C) because of the later age of first mating of Bligon goats, the length of the age of first kidding. In addition, if the $\mathrm{S} / \mathrm{C}$ is more than once, then the age of the first kidding will also be high because the second mating would be postponed, waiting for the next oestrus cycle. The age of first kidding could be influenced by the breed of goats, the quality of the feed given during pregnancy, and the reproductive management of Bligon goats.

\subsection{Postpartum Mating (PPM)}

Post-partum mating (PPM), or the first mating after birth, is a mating that occurs after the does give birth to the first and the kid has been weaned. PPM of Bligon goats in different agro-ecological zones had a significant difference $(\mathrm{P}<0.05)$ with $\mathrm{PPM}$ in the lowland was 4.75 months while the hilly area was 4.9 months (Table 1 ) and longer than the previous research, which was 4.0 months in the first group and 4.3 months in the second group [12] and 4.38 months in the lowland and 4.07 months in the hilly area [4]. The longer PPM in this study was caused by the insufficient knowledge of farmers regarding reproductive problems so that farmers will only re-mate Bligon goats after the kids were weaned. Higher PPM and more than one service per conception time will affect the productivity of Bligon goats, the age of first kidding, and PPM.

\subsection{Kidding Interval (KI)}

Kidding interval $(\mathrm{KI})$ is the period between two times of kidding, consisting of the mating period (the period from previous kidding to the next kidding) and the length of pregnancy [9]. 
Table 1. Reproductive performances of Bligon goats in lowland and hilly area in Bantul Regency,

\begin{tabular}{|c|c|c|}
\hline \multirow{2}{*}{ Description } & \multicolumn{2}{|c|}{ Agroecological Zones } \\
\hline & Lowland & Hilly Area \\
\hline \multicolumn{3}{|l|}{ Ability to detect estrus (\%) } \\
\hline a. Poor & 52.38 & 45.83 \\
\hline b. Medium & 0 & 25.00 \\
\hline c. Good & 19.05 & 20.83 \\
\hline d. Excellent & 28.57 & 8.33 \\
\hline \multicolumn{3}{|l|}{ Mating methods (\%) } \\
\hline a. Natural mating & 90.48 & 100.00 \\
\hline b. Artificial insemination (Al) & 9.52 & 0.00 \\
\hline \multicolumn{3}{|l|}{ Reproductive management } \\
\hline a. Age of first mating (months) & $9.60 \pm 3.22^{a}$ & $11.07 \pm 2.41^{b}$ \\
\hline \multicolumn{3}{|l|}{ Reproductive performances } \\
\hline a. Length of pregnancy (months) ${ }^{\text {ns }}$ & $5.07 \pm 0.26$ & $5.10 \pm 0.30$ \\
\hline b. Age of first kidding (months) & $15.00 \pm 3.23^{a}$ & $16.70 \pm 2.53^{b}$ \\
\hline c. Postpartum mating (PPM) (months) & $4.75 \pm 2.23^{a}$ & $4.9 \pm 2.34^{b}$ \\
\hline d. Kidding interval (months) ${ }^{\text {ns }}$ & $9.32 \pm 3.53$ & $9.37 \pm 3.83$ \\
\hline e. Litter size (kid) & $1.62 \pm 0.58^{a}$ & $1.37 \pm 0.49^{b}$ \\
\hline
\end{tabular}

${ }^{a, b}$ Means with different superscripts on the same line are significantly different $(\mathrm{P}<0.05)$

${ }^{n s}$ Non-significant

Kidding interval is one of the reproductive parameters that affect population increase, livestock productivity level, and reproductive efficiency evaluation index in a female goat. The shorter KI will produce higher reproductive efficiency because a reproductive pattern that follows the reproductive calendar to birth three times in two years can be achieved. The KI in the lowland agroecological zone was 9.32 months, and in the hilly area was 9.37 months (Table 1). The statistical analysis showed that there was no significant difference in kidding intervals between lowland and hilly are. The kidding intervals of Bligon goats reared in rural areas were 7 to 12 months [9,10], 9.41 months in the lowland, and 9.09 months in the hilly area [5]. A long time of kidding intervals will affect further productivity, and the goat population owned by farmers will not increase.

\subsection{Litter Size (LS)}

Litter size (LS), or the number of kids born in one birth, is one of the parameters of livestock productivity in contributing to population increase because it determines the fertility rate of female and goat population growth [11]. There was a significant difference $(\mathrm{P}<0.05)$ in litter size. It was 1.62 in the lowland and 1.37 in the hilly area (Table 1). The result of this study was lower than the previous study, which found 1.73 kids per birth in Bligon goats [9]. Litter size is influenced by genetic factors, female age factors, body weight and nutritional level [13], environment and microclimate where the cattle were kept [14], level of feed consumption, feeding with higher nutrient levels at the same time before ovulation will increase the number of ovum ovulated [13].

On average, Bligon goats in lowland and hilly areas could produce more than one kid at each birth (prolific). The prolific trait is one of the reproductive traits, namely the ability to give birth to more than one head per birth. The prolific characteristic of each goat is different because it is affected by genetic variations from the parents, which causes an increase in ovulation rate and litter size. Litter size in Bligon goats is due to parental factors, namely Kacang goat and Etawah Grade goat. The Kacang goat, as the parent of the Bligon goat, does have a relatively small body size. However, the Kacang goat has better reproductive characteristics, namely the ability to give birth to more than one high (prolific) and is well adapted to extreme environments such as limited feed availability and low quality [15].

\section{CONCLUSIONS}

The reproductive performance of Bligon goats is better in the lowland than in the hilly area in terms of first mating age, first kidding age, post-partum mating (PPM), and litter size. Better reproductive performances of Bligon goats in lowland areas have been supported by better farmers' ability to detect the oestrus cycle; $28.57 \%$ of farmers in the lowland have an excellent ability compared to farmers in a hilly area. 


\section{AUTHORS' CONTRIBUTIONS}

All authors conceived and planned the experiments. LKW carried out the experiments. IGSB, BA and LKW took the lead in writing the manuscript. All authors contributed to interpreting the results, provided critical feedback, and helped shape the research, analysis, and manuscript.

\section{ACKNOWLEDGMENTS}

The authors are thankful to the Ministry of Research and Technology/National Agency for Research and Innovation, the Republic of Indonesia, for funding this study with grant no. 6/E1/KP.PTNBH/2021 and contract no. 2196/UN1/DITLIT/DIT-LIT/2021).

\section{REFERENCES}

[1] IGS. Budisatria, H.M.J. Udo, Goat-based aid programme in Central Java: An effective intervention for the poor and vulnerable? Small Ruminant Research, vol. 109, 2013, pp. 76-83. DOI: https://doi.org/10.1016/i.smallrumres.2012.07.01 9

[2] T.T. Mhlanga, T. Mutibyu, D.T. Mbiriri, Goat flock productivity under smallholder farmer management in Zimbabwe, Small Ruminant Research, vol. 164, 2018, pp. 105-109. DOI: https://doi.org/10.1016/j.smallrumres.2018.05.01 $\underline{0}$

[3] IGS. Budisatria, H.M.J. Udo, CHAM Eilers, A.J. Van Der Zijpp, Dynamics of small ruminant production: A case study of Central Java, Indonesia Outlook Agriculture, vol. 36, 2007, pp. 145-152. DOI: https://doi.org/10.5367/000000007781159976

[4] Rahmawati, R.D., B.A. Atmoko., I.G.S. Budisatria., N. Ngadiyono and Panjono, 2022. Exterior characteristics and body measurements of Bligon goat on the different agro-ecological zones in Bantul District, Yogyakarta, Indonesia. Biodiversitas. 23(1) (2022) 143-150. DOI: http://dx.doi.org/10.13507/biodiv/d230118

[5] IGS. Budisatria, H.M.J. Udo, CHAM Eilers, E. Baliarti, A.J. Van Der Zijpp, Preferences for sheep or goats in Indonesia, Small Ruminant Research, vol. 88, 2010, pp. 16-22. DOI: http://doi.org/10.1016/j.smallrumres.2009.11.002

[6] R. Adiwinarti, Kustantinah, I.G.S. Budisatria, Rusman, E. Indarto, Improving the performance of local Kacang goats using ruminally undegradable protein feeds, Asian Journal Animal Science, vol. 10, 2016, pp. 262-267. DOI:

\subsection{3/ajas.2016.262.267}

[7] HMJ Udo, IGS. Budisatria, Fat-tailed sheep in Indonesia: An essential resource for smallholders, Tropical Animal Health Production, vol. 43, 2011, pp. 1411-1418. DOI: https://doi.org/10.1007/s11250-011-9872-7

[8] S. Usman, Abdullah, Sahrir, Produktivitas ternak kambing lokal di Kabupaten Tolitoli, Jurnal Sains dan Teknologi Tadulako, vol. 5, 2016, pp. 87-95. ISSN: 2089-8630

[9] G. Murdjito, I.G.S. Budisatria, Panjono, N. Ngadiyono, E. Baliarti, Performances of Bligon goat kept by farmers at Giri Sekar Village, Panggang, Gunung Kidul, Buletin Peternakan, vol. 35, 2011, pp. 86-95. DOI: https://doi.org/10.21059/buletinpeternak.v35i2.5 $\underline{95}$

[10] IGS. Budisatria, Panjono, N. Ngadiyono, B.A. Atmoko. The productivity comparison between Bligon and Kejobong Goats in Indonesia, based from on-farm and on-station research, Journal Animal Health Production, vol. 9, 2021, pp. 262270.

DOI: http://dx.doi.org/10.17582/journal.jahp/2021/9.3. $\underline{262.270}$

[11] F. Parasmawati, Suyadi, S. Wahyuningsih, Performan reproduksi pada persilangan kambing Boer dan Peranakan Etawah (PE), Jurnal IlmuIlmu Peternakan, vol. 23, 2016, pp. 11-17. ISSN: 0852-3581

[12] W.L. Werdhany, Gunawan, Performans reproduksi induk Kambing Bligon di peternak Desa Banjarharjo, Kalibawang, Kulon Progo, Proceedings of the Seminar Nasional Pembangunan Peternakan Indonesia Berbasis Riset Inovatif. Sebelas Maret University. Surakarta, 2014, pp. 51-56. ISBN: 978-60272254-0-4

[13] M. Doloksaribu, S. Elieser, F. Mahmilia, F.A. Pamungkas, Produktivitas kambing Kacang pada kondisi dikandangkan: Bobot lahir, bobot sapih, jumlah anak sekelahiran, dan daya hidup anak prasapih, Proceedings of the Seminar Nasional Teknologi Peternakan dan Veteriner, Bogor, 2005, pp. 581-585.

[14] W. Hardjosubroto, Aplikasi Pemuliabiakan Ternak di Lapangan, PT Grasindo, Jakarta, 1994

[15] R.A. Hidayat, S.N. Depamede, M. Maskur. Identifikasi mutasi FecX pada gen BMP15 dan pengaruhnya terhadap sifat prolifik pada kambing lokal di Kabupaten Lombok Barat. Jurnal Ilmu dan Teknologi Peternakan Indonesia, vol. 1, 2019, pp. 1-10. DOI: https://doi.org/10.29303/jitpi.v1i1.3 